\title{
山腹工における植生回復のための基盤条件
}

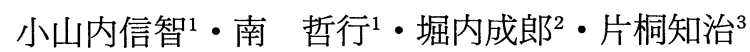

\section{Condition of Foundation for Revegetation at Hillside Work Area}

\author{
Osanai, Nobutomo ${ }^{1}$, Minami, Noriyuki ${ }^{1}$, HorIUCHI, Shigeo ${ }^{2}$ and KATAGIRI, Chiharu ${ }^{3}$ \\ 要旨
}

\begin{abstract}
砂防事業および治山事業等に扔いては土砂の流出抑制を目的として山腹斜面の整備が実 施されるが，その整備・管理目標としては，(1)植生が発達して被覆がなされているか，(2) リ夕一等の供給により $\mathrm{A}_{0}$ 層が形成されているか, (3)根系の発達が十分か, (4)人為的管理を 強く行わなくても自然な遷移が進行する群落が形成されているか，(5)自然下種による植生 の発達が可能な土壤がそれまでに確保されているか, といった遷移中・後期の基盤条件ま でを考慮して設定すべきであると考元れる。その中で, 山腹工施工地において成立して いる森林の斜面安定化効果としての根系の発達, おょび地上植生の発達状況に対して, 土 壤条件の違いがどの程度影響を与えているのかを把握し, 山腹工施工の際の配慮事項を示 すことを目的に，岐皁県多治見市周辺の山腹斜面において根系調査および土壌調査を行っ た。根系の発達は土壤の軟らかい層では概ね良好であったが, 通気性の悪い層では細根の

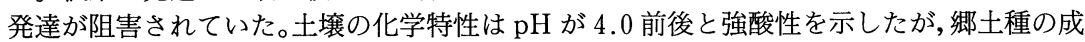
長に対しては問題はないと考えられた。B 層は貧栄養傾向であるが, 褐色森林土垣が形成 されている地区の樹木の成長は良好であった。山腹工の施工に際しては土壤硬度, 通気性, 養分を考慮した生育基盤整備を行うことが必要と考えられた。
\end{abstract}

\section{1. はじめに}

近年の砂防工事は砂防ダムや流路工等の渓流工事 が主体となっていたが, 渓流環境への負荷を極力軽 減し, 面的な土砂流出抑制対策を行うために, 山腹

キーワード : 山腹工, 生育基盤, 土壤調査, 根系, 砂防事 業

Key words : Hillside work, Growth foundation, Soil survey, Root system, Erosion and sediment control

1 建設省土木研究所砂防研究室

Erosion and Sediment Control Div., Public Works Res. Inst., M.O.C.

2 和歌山県土木部砂防課（前建設省中部地方建設局多治見 工事事務所)

Erosion Control Div., Public Works Dept., Wakayama Pref.

3 建設省中部地方建設局多治見工事事務所

Tajimi Work Office, Chubu Regional Construction Bureau, M.O.C.
斜面管理のあり方が再度活発に議論され始めた。

ところで, 砂防事業等で実施する山腹工は秃しゃ 地あるいは崩壊地に植生を導入し, 表土の風化, 侵 食, 崩壊の拡大を防止して, 土砂生産の抑制を図る ことを目的とするものであり ${ }^{5}$, したがって, 植生の 成立基盤を確保するための山腹基礎工・山腹緑化工 の施工とその後の植生管理の両者を行うことによっ てその機能を発揮させることが必要である。

山腹工施工による表層土の流出抑制効果に関する 観測は瀬田川上流等で実施されてきており ${ }^{3,7}$, 山腹 基礎工・山腹緑化工は施工それ自体が表土の移動を 抑制することになるため, 流出土砂量の減少という 目標の大部分を直ちに達成できることが示されてい る。同時に，表土の移動抑制は導入樹木等が成長す るための場の条件の整備であり, 基礎工等の構造的 機能が減少するまでの間に植生の発達を目指し, 最 終的には土砂流出ポテンシャルが周辺自然斜面と近 
似すればよいと考えられる。

植生が発達することによる土砂流出抑制効果は一 般に, I . 地表面保護機能, II. 土の強度補強機能, の 2 つに大きく分類できる ${ }^{8)}$ 。I については植生(主 に草本) の存在による被覆, $\mathrm{A}_{0}$ 層の形成による表流 水の発生抑止，および水平根のネット形成によるり ル・ガリーの形成抑制 ${ }^{9)}$, II については根系の発達に

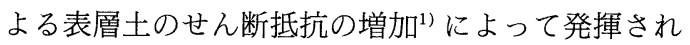
る。

したがって，山腹斜面の整備・管理目標としては， 直接的には，(1)植生が発達して被覆がなされている か, (2)リタ一等の供給により $\mathrm{A}_{0}$ 層が形成されてい るか, (3)膨軟した土袞の存在に対して根系の発達が 十分か, という 3 点になるが, 山腹工においては導 入植生が遷移することが一般的であり, 周辺の自然 植生構成種の侵入を含め, 極相に向かう自然遷移が スムーズに行われることが必要である。

細川ら ${ }^{2)}$ の報告によれば，滋賀県の瀬田川流域の 田上地区および信楽地区の山腹工施工地において は, 施工後 30 年の調査区では植栽木のクロマツが 立木本数割合で 10 ～ $20 \%$, 材積割合で 60 ～70\%を 占めているが, 50 年区ではアカマツに主体を移し, 100 年区ではさらに広葉樹に遷移している。また, 土 猿の発達状況は, 30 年区では $\mathrm{B}$ 層が形成されておら ず， 50 年区で生成初期の B 層が，100 年区では自然 土壤に近い $\mathrm{B}$ 層が $30 \mathrm{~cm}$ 程度の深さまで認められ ている。

このように, (4)人為的管理を強く行わなくても自 然な遷移が進行する群落が形成されているか, (5)自 然下種による植生の発達が可能な土壤がそれまでに 確保されているか，といった遷移中・後期の条件も 考慮した整備・管理を行うべきと考えられる。

しかしながら，施工斜面自体の安全性や森林とし ての安定性・成熟度に関する評価は必ずしも十分に なされてはいない。そこで，古くから行われてきた 山腹工が数十年を経て山腹の植生生育基盤としてど のように寄与しているのかを検証し, 合理的かつ効 率的な斜面整備および管理のあり方を検討するた め, 山腹工施工地における植生の回復過程を整理す るとともに, 岐阜県多治見市周辺において, 施工後 約 40 年を経過した山腹工施工地とその対照区の樹 木根系および生育基盤としての土壤の発達状況に着 目して実態把握を行った。

\section{2. 調査地点および調査木の選定}

\section{1 調査地点}

上述のような斜面管理のための具体的な指標を得 るため, 岐阜県南東部の庄内川流域の 4 地区を調査 区域とした。同地方は古くから羹業が盛んで，陶土 採掘および燃料としての木材の伐採が激しく山地の 荒廃・秃しゃ地化が進んだため，土砂流出の抑制を 目的とした山腹工等の砂防事業が明治時代から続け られてきた。

抽出した調査区は，(1)既往山腹工施工箇所とし て, 昭和 31 年に山腹工 (等高線壕工)を施工したが, 現在は樹木の成長が停滞し，一部にマツクイムシ被 害によるマツ類の荒廃が見られる森下地区（A 地 区), (2)頂部の植生が分弱で今後山腹工の施工が必要 と考えられる箇所として上原地区(B 地区)，(3)樹木 生育の良好な箇所として星ヶ台地区 (C 地区), (4)長 期的な目標とする良好な樹林として，庄内川流域の 砂防区域内に抢いて潜在自然植生と考えられるアラ カシ林の認められる虎渓山地区(D 地区)，の 4 地区 である。

なお，これらの地区の表層地質はいずれも新第三 系土岐砂礫層である。

\section{2 調査木}

各斜面の現況植生状況（枯損木の多少，樹林の粗 密で判断した）と土壤および根系の発達状況との関 係を把握するために，各調查地区・斜面位置におい て樹高および胸高直径が平均的で, 生育状況が周辺 植生を代表していると考えられる樹木を表 1 に示し たとおり選定した。なお，A，B，C地区については 常緑針葉樹としてアカマツを, 落葉広葉樹としてコ ナラを選定し，D 地区については常緑広葉樹のアラ カシと落葉広葉樹のコナラを選定した。

各調査木のある斜面は, No. 6 がやや谷地形にな っているのを除いてはいずれも尾根部側面の流水が 集中することのない斜面である。

\section{3. 調查方法}

各調査対象木に対し, 土壌断面調查, 根系調査, 土猿硬度調査, 土壤分析を行った。

土壤断面調査は, 調查木の樹心から約 $50 \mathrm{~cm}$ 離れ たところに，およそ「(縦; $1 \mathrm{~m}) \times($ 横; $1 \mathrm{~m}) \times($ 深さ; C 層の出現するところまで)」を目安に調查用試坑を 掘り, 土㙴層位区分後, 各層位における土性, 土色, 
表 1 調査木諸元

Table 1 General characteristics of the study plants

\begin{tabular}{|c|c|c|c|c|c|c|c|c|}
\hline 地 区 & 植生状況 & 斜面位置 & No. & 樹＼cjkstart種 & 樹高 (m) & $\begin{array}{c}\text { 胸高直径 } \\
(\mathrm{cm})\end{array}$ & $\begin{array}{c}\text { 根元直径 } \\
(\mathrm{cm})\end{array}$ & $\begin{array}{c}\text { 斜面傾斜 } \\
\text { (度) }\end{array}$ \\
\hline \multirow{6}{*}{$\begin{array}{l}\text { 森下地区 } \\
\text { (A 地区) }\end{array}$} & \multirow{6}{*}{ 不良 } & \multirow[t]{2}{*}{ 頂部 } & 1 & コナラ & 6.2 & 6.4 & 8.9 & 18 \\
\hline & & & 2 & アカマツ & 10.5 & 17.8 & 21.3 & 28 \\
\hline & & \multirow[t]{2}{*}{ 中部 } & 3 & コナラ & 7.5 & 11.8 & 15.6 & 34 \\
\hline & & & 4 & アカマツ & 10.5 & 14.6 & 20.1 & 23 \\
\hline & & \multirow[t]{2}{*}{ 下部 } & 5 & コナラ & 8.5 & 13.1 & 19.1 & 32 \\
\hline & & & 6 & アカマツ & 15.0 & 22.6 & 28.0 & 33 \\
\hline \multirow{3}{*}{$\begin{array}{l}\text { 上原地区 } \\
\text { (B1 地区) }\end{array}$} & \multirow[t]{2}{*}{ 不良 } & \multirow[t]{2}{*}{ 頂部 } & 7 & コナラ & 5.7 & 5.7 & 9.5 & 9 \\
\hline & & & 8 & アカマツ & 8.5 & 12.1 & 17.8 & 14 \\
\hline & \multirow{4}{*}{ 普通 } & 中部 & 9 & コナラ & 4.2 & $3.5,6.5$ & $5.6,10.0$ & 26 \\
\hline \multirow{3}{*}{$\begin{array}{l}\text { 上原地区 } \\
\text { (B2 地区) }\end{array}$} & & & 10 & アカマツ & 9.0 & 11.8 & 15.3 & 28 \\
\hline & & 下部 & 11 & コナラ & 8.4 & 9.9 & 12.7 & 32 \\
\hline & & & 12 & アカマツ & 16.0 & 16.6 & 22.9 & 32 \\
\hline \multirow{2}{*}{$\begin{array}{c}\text { 星ケ台地区 } \\
\text { (C 地区) }\end{array}$} & \multirow[t]{2}{*}{ 良好 } & \multirow[t]{2}{*}{ 下部 } & 13 & コナラ & 14.0 & 13.1 & 18.8 & 12 \\
\hline & & & 14 & アカマツ & 16.0 & 20.4 & 24.8 & 22 \\
\hline \multirow{2}{*}{$\begin{array}{c}\text { 虎渓山地区 } \\
\text { (D 地区) }\end{array}$} & \multirow[t]{2}{*}{ 良好 } & \multirow[t]{2}{*}{ 頂部 } & 15 & アラカシ & 13.5 & 18.2 & 23.2 & 23 \\
\hline & & & 16 & コナラ & 15.0 & $23.0, \quad 20.2$ & 41.7 & 16 \\
\hline
\end{tabular}

表 2 土壌生成と根系分布

Table 2 Soil formation and development of root system

\begin{tabular}{|c|c|c|c|c|c|c|c|}
\hline 地 区 & 植生状況 & 土㙵型 & \multicolumn{2}{|c|}{ 層位・層厚 $(\mathrm{cm})$} & 土 性 & $\begin{array}{c}\text { 軟らかい土層厚 } \\
(\mathrm{cm})\end{array}$ & $\begin{array}{c}\text { 主要根群分布域深さ } \\
(\mathrm{cm})\end{array}$ \\
\hline A & 不良 & $\begin{array}{l}\text { 未熟土 } \\
\text { (受蝕型) }\end{array}$ & $\begin{array}{l}\mathrm{A}_{0} \text { 層 } \\
\mathrm{A} \text { 層 } \\
\mathrm{B} \text { 層 }\end{array}$ & $\begin{array}{r}12.6 \\
10.3 \\
9.2\end{array}$ & $\begin{array}{l}\mathrm{L}, \mathrm{SL} \\
\mathrm{L}, \mathrm{SL}\end{array}$ & $12 \sim 26$ & $\begin{array}{r}\text { コナラ : } 20 \sim 30 \\
\text { アカマツ : } 25 \sim 40\end{array}$ \\
\hline B1 & 不良 & $\begin{array}{l}\text { 未熟土 } \\
\text { (受蝕型) }\end{array}$ & $\begin{array}{l}\mathrm{A}_{0} \text { 層 } \\
\mathrm{A} \text { 層 } \\
\mathrm{B} \text { 層 }\end{array}$ & $\begin{array}{r}6.0 \\
6.0 \\
13.0\end{array}$ & $\begin{array}{l}\mathrm{L}, \mathrm{SL} \\
\mathrm{L}, \mathrm{CL}\end{array}$ & $19 \sim 21$ & $\begin{aligned} \text { コナラ : } & 30 \\
\text { アカマツ : } & 33\end{aligned}$ \\
\hline B2 & 普通 & $\begin{array}{l}\text { 末熟土的な } \\
\text { 乾性黄色系 } \\
\text { 褐色森林土 }\end{array}$ & $\begin{array}{l}\mathrm{A}_{0} \text { 層 } \\
\mathrm{A} \text { 層 } \\
\mathrm{B} \text { 層 }\end{array}$ & $\begin{array}{r}7.6 \\
8.0 \\
48.8\end{array}$ & $\begin{array}{l}\text { SL, CL } \\
\text { CL, LiC }\end{array}$ & $57 \sim 82$ & $\begin{array}{r}\text { コナラ : } 40 \sim 43 \\
\text { アカマツ : } 38 \sim 48\end{array}$ \\
\hline C & 良好 & $\begin{array}{l}\text { 乾性黄色系 } \\
\text { 褐色森林土 }\end{array}$ & $\begin{array}{l}\mathrm{A}_{0} \text { 層 } \\
\mathrm{A} \text { 層 } \\
\mathrm{B} \text { 層 }\end{array}$ & $\begin{array}{r}6.0 \\
9.0 \\
66.5\end{array}$ & $\begin{array}{l}\mathrm{L}, \mathrm{SL} \\
\mathrm{CL}\end{array}$ & $65 \sim 73$ & $\begin{aligned} \text { コナラ: } & 80 \\
\text { アカマツ : } & 90\end{aligned}$ \\
\hline $\mathrm{D}$ & 良好 & $\begin{array}{l}\text { 乾性黄色系 } \\
\text { 褐色森林土 }\end{array}$ & $\begin{array}{l}\mathrm{A}_{0} \text { 層 } \\
\mathrm{A} \text { 層 } \\
\mathrm{B} \text { 層 }\end{array}$ & $\begin{array}{r}7.5 \\
4.5 \\
82.5\end{array}$ & $\begin{array}{c}\mathrm{L} \\
\mathrm{CL}, \mathrm{LiC}\end{array}$ & $93 \sim 97$ & $\begin{array}{rr}\text { アラカシ : } & 100 \\
\text { コナラ : } & 95\end{array}$ \\
\hline
\end{tabular}

水湿状態, 土䁃構造, 砅含有量を調査した。

根系調査は，土壤断面調査終了後，樹木の根元ま での土壌を掘り，根系を露出させてその発達状況を 観察した。

土壌硬度調査は, 調査対象木の樹心より約 $50 \mathrm{~cm}$
離れた位置で, 長谷川式土壤貫入計 $(2 \mathrm{~kg}$ のランマ 一を落下距離 $50 \mathrm{~cm}$ で, $\phi=20 \mathrm{~mm} ・$ 先端角 $60^{\circ}$ の貫 入コーンを持つロッドに落とす)を用いて, 1 回の落 下当たりの貫入深 $(\mathrm{cm})$ を軟らか度 $(S$ 值）として 測定した。また，山中式土壤硬度計を用い, 同一の 


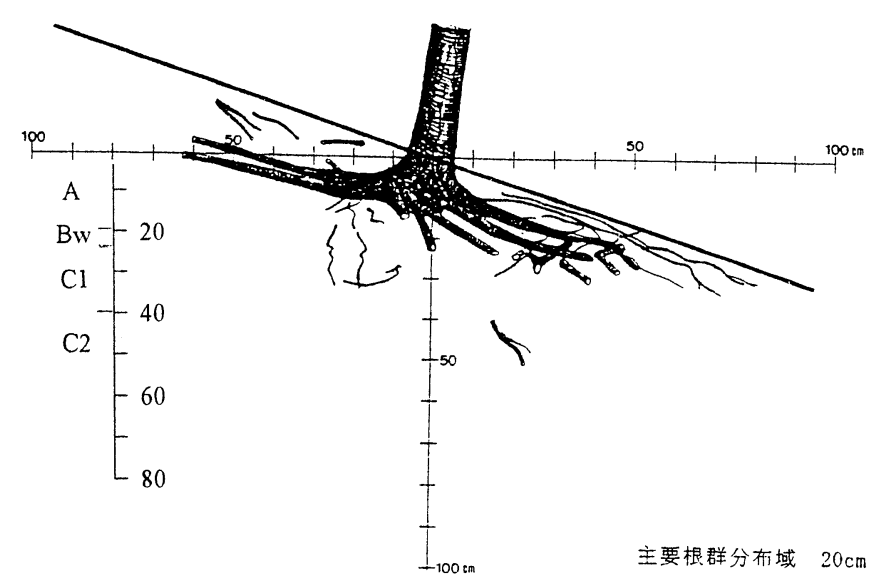

(a) No. 1 コナラ (A 地区)

(a) No. 1 Quercus serrata (Area A)

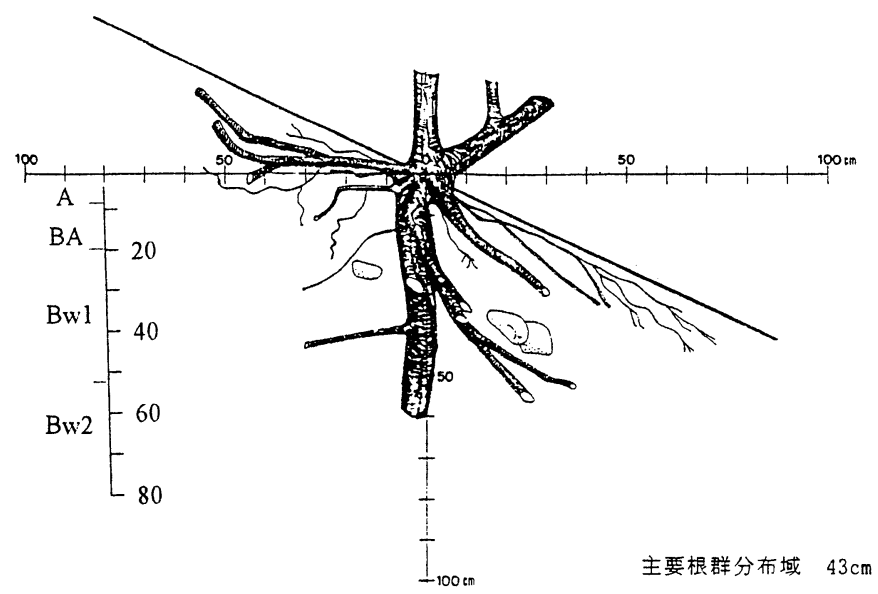

(b) No. 9 コナラ (B2 地区)

(b) No. 9 Quercus serrata (Area B2)

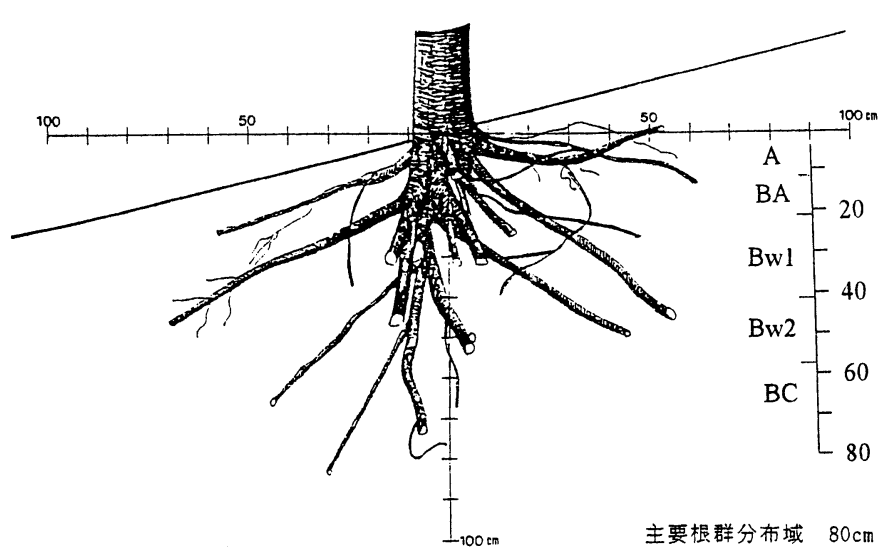

(c) No. 13 コナラ (C 地区)

(c) No. 13 Quercus serrata (Area C)

图 1 根系分布状況

Fig. 1 Development of the root system 
層位で場所を変えて 5 回測定し，算術平均によって 平均土袞硬度とした。

土壤分析は, 土㗒断面調查で採取した土袞を風乾 後, $2 \mathrm{~mm}$ 篩別を行った試料を用い, $\mathrm{pH}\left(\mathrm{H}_{2} \mathrm{O}\right)(1$ ： 2.5 ガラス電極法), 電気伝導度 (1: 5 水浸出法), 全炭素 (乾式燃焼法), 全窒素 (乾式燃焼法) の 4 項 目について行った。

\section{4. 調査結果と考察}

\section{1 土㙵構造と根系分布状況}

土壤断面調査 ${ }^{6}$, 土溒硬度調査, 根系調查の結果を 表 2 に示した。なお,「層厚」は地区ごとの算術平均 であり,「軟らかい土層の厚さ」とは $\mathrm{A}$ 層の表面か ら $S$ 值が $1.0 \mathrm{~cm} / \mathrm{drop}$ 未満, 山中式土㙵硬度計で $24 \mathrm{~mm}$ 以上の值を示す深さまでの土層の厚さをい う。

以下に，各地区ごとの土壌と根系分布の状況を述 べる。

A, B 1 地区：軟らかい土層厚が $20 \mathrm{~cm}$ 程度と薄 く, 「主要根群分布域」(杭根以外の根系が集中的に 分布している深さ方向の範囲）はそれよりも若干深 い程度までであった(図 1(a))。ただし，アカマツに ついてはNo. 4 が側方に伸長しているのを除き，杭 根が $50 \mathrm{~cm}$ 程度まで侵入して支持根となっていた。

B 2 地区：軟らかい土層は $80 \mathrm{~cm}$ 程度と比較的厚 いが, 主要根群分布域は $40 \mathrm{~cm}$ 程度に留まってい た。これは, 粘質土が多くを占め, 深さ $40 \mathrm{~cm}$ 程度 のところでカべ状を呈し，緻密で孔隙が少なくなる ため細根の呼吸が阻害されるためと考えられる。実 際に，それ以下の深さには腐朽根が認められた。ま
た，コナラ，アカマツともに $60 \sim 80 \mathrm{~cm}$ 程度まで杭 根は侵入しているが，中径の斜出根が緻密な土壤を 避けて斜面に水平に発達しているのが特徵的であっ た(図1(b))。

C 地区：コナラ,アカマツともに, 特定の深さで伸 長が制限されることなく根系が発達している（図 1(c)）。主要根群分布域は軟らかい土層厚よりも若 干深い位置まで到達していた。

$\mathrm{D}$ 地区：C 地区と同様に，アラカシ，コナラとも に抑圧のない根系発達をしている。主要根群分布域 は軟らかい土層厚とほぼ同じ $100 \mathrm{~cm}$ 程度まで到達 していた。

\section{2 土壌化学特性分析結果}

表 3 に土壌の化学特性分析結果を示した。一般的 な樹木の生育と土壤分析值の関係 ${ }^{4)}$ を参考に, 各調 査区の特性を以下に述べる。

$\mathrm{pH}\left(\mathrm{H}_{2} \mathrm{O}\right)$ についてはいずれの地区もほぼ同様の 強酸性を示した。これは珪酸分を多く含む多治見市 周辺の土壤の特性であるが, $\mathrm{A}$ 層の方が $\mathrm{B}$ 層よりも $\mathrm{pH}$ 值が小さいのは, 各調査地点の $\mathrm{A}_{0}$ 層が厚く残つ ていることからも，この地域の年降水量が 1,500 $\mathrm{mm}$ 程度と比較的少ないことから有機物の腐食が進 みにくく, 酸性反応の強い粗腐食層の影響が現れて いる可能性がある。この $\mathrm{pH}$ 值は一般的には改良を 要するレベルであるが, 特に酸性度の強い $\mathrm{D}$ 地区に おいても樹木の成長に支障がみられないことから， 郷土種を成立させることを目標にするならば大きな 問題はないと考えられた。

電気伝導度は塩類の総量を示す指標であり，本調 査地において濃度障害の恐れはないが，D 地区を除

表 3 土㗒の化学特性分析

Table 3 Chemical characteristics of the soil

\begin{tabular}{|c|c|c|c|c|c|c|}
\hline 地 区 & 層位 & $\mathrm{pH}\left(\mathrm{H}_{2} \mathrm{O}\right)$ & 電気伝導度 $(\mathrm{mS} / \mathrm{cm})$ & 全炭素(\%) & 全窒素(\%) & $\mathrm{C} / \mathrm{N}$ \\
\hline \multirow{2}{*}{ A } & A 層 & $3.8 \sim 4.2$ & $0.04 \sim 0.08$ & 2.02 & 0.10 & 20.2 \\
\hline & $\mathrm{B}$ 層 & $4.2 \sim 4.7$ & $0.02 \sim 0.04$ & 0.61 & 0.02 & 30.5 \\
\hline \multirow{2}{*}{$\mathrm{B} 1$} & $\mathrm{~A}$ 層 & $3.9 \sim 4.2$ & $0.05 \sim 0.06$ & 2.13 & 0.10 & 21.3 \\
\hline & $\mathrm{B}$ 層 & $4.4 \sim 4.5$ & 0.03 & 0.60 & 0.03 & 20.0 \\
\hline \multirow{2}{*}{ B2 } & $\mathrm{A}$ 層 & $4.1 \sim 4.3$ & $0.04 \sim 0.06$ & 2.45 & 0.12 & 20.4 \\
\hline & $\mathrm{B}$ 層 & $4.3 \sim 4.5$ & $0.03 \sim 0.04$ & 0.25 & 0.02 & 12.5 \\
\hline \multirow{2}{*}{$\mathrm{C}$} & $\mathrm{A}$ 層 & $4.4 \sim 4.5$ & $0.04 \sim 0.05$ & 2.60 & 0.14 & 18.6 \\
\hline & $\mathrm{B}$ 層 & $4.4 \sim 4.6$ & $0.03 \sim 0.04$ & 0.30 & 0.03 & 10.0 \\
\hline \multirow{2}{*}{ D } & $\mathrm{A}$ 層 & $3.6 \sim 3.8$ & $0.12 \sim 0.13$ & 5.11 & 0.26 & 19.7 \\
\hline & B 層 & $4.3 \sim 4.5$ & $0.04 \sim 0.05$ & 0.74 & 0.04 & 18.5 \\
\hline
\end{tabular}


いては樹木の生育に優良とされる 0.05 を下回るも のが多く，むしろ貧栄養傾向と考えられた。

全炭素・全窒素は, A 層については D 地区で良好 なのを除いては正常〜やや不足, $\mathrm{B}$ 層については不 足のレベルであった。なお， A および B 1 地区の B 層の全炭素値が B 2，C 地区のものに比べて大きな 值を示しているが,これは $\mathrm{B}$ 層の厚さの違いによっ て土壌サンプル採取位置における表層からの腐食供 給割合の相対的な差として現れたものと考えられ る。

$\mathrm{C} / \mathrm{N}$ 比でみると, 植生状況の不良な $\mathrm{A}, \mathrm{B} 1$ 地区 とそれ以外の B 2, C, D 地区との間で若干の差がみ られたが，A 層では差が小さく， B 層では差はやや 大きいものの炭素, 窒素の絶対量が元々小さいの で，樹木の生育に対する影響はそれほど大きくはな いと考えられた。

$\mathrm{A}$ 層の厚さは各地区で大きな違いはないものの, 植物の生育が良好な $\mathrm{C}, \mathrm{D}$ 地区では褐色森林土壤が 形成されており，また，C地区は D 地区に比べて土 壤化学性ではやや劣るが $\mathrm{B}$ 層の厚さはほぼ匹敵す ることから, A, B 層の化学的性質よりも $\mathrm{B}$ 層の「厚 さ」やその「軟らかさ」等の物理的性質が整ってい ることの方が樹木の成長にとってより支配的である ことを示唆している。すなわち, 植生導入の初期に おいて, 施肥など若干の土堙化学性の改善は必要と しても, 土㙵物理性の改善が導入植生の生育性改善 にとって極めて有効であるということが言えよう。

\section{3 山腹工施工時の配慮事項}

調査結果より, 植生および根系の健全な発達とい う点に着目して, 山腹工施工時の配慮事項を以下の ように整理した。

山腹工施工箇所においても基盤の条件が悪い場合 には植生の維持に支障がみられ, 一方, 軟らかい表 土の厚さが $70 \mathrm{~cm}$ 程度まで存在する場合には, ほぼ 阻害を受けない状態の根系の発達がみられた。ただ し, 通気性の悪い層が途中に存在する場合には, そ こで細根の発達が阻害されることになる。また, 肥 沃度の面からは, 形成されている A 層は樹木の成長 にとって大きな問題はないと考えられたが，B 層は 貧栄養であるため, ある程度早急に森林を成立させ ることを目標とする場合の山腹工施工に際しては, 基盤となる土壤の条件を整える必要が生ずる場合が あると考えられる。

山腹工の施工が必要な斜面は, 元来 $\mathrm{A} \sim \mathrm{B}$ 層が薄
く表土が常に表流水等により移動している場合が多 いため, 植物の自然侵入が期待しにくい場所であ る。したがって，山腹工において植生回復を行うに は基礎処理を施すのが一般的であり，また斜面の勾 配を整えるには現地の表土を切り盛りすることにな るため, その際に「軟らかさ」,「通気性」,「ある程 度の養分」等の条件を満たす疑似 $\mathrm{A} \sim \mathrm{B}$ 層を一定以 上の深さで形成する地盤改良を伴うような施工を行 うことが早期の樹林帯形成に有効であると考えられ る。

\section{4 今後の課題}

本調査はごく限られた条件のものであるため, 今 後, 他の地質条件等の山腹工施工地の土壤発達状 況，植生遷移状況，侵入樹木の平面および垂直方向 の根系分布実態を調査する必要がある。また，樹木 の成長に大きな影響を与える窒素やリン等の栄養元 素については可給態としての存在状況を含め, より 詳細な分析を行う必要がある。さらに既往の山腹工 の安定性を評価することで, 土砂流出抑制のための 合理的な山腹斜面管理のあり方を明確にすることが できると考えている。

\section{5. まとめ}

効率的な山腹工施工のあり方を検討するために， 施工後約 40 年を経過した山腹工施工地とその対照 区について，土壤調査扔よび根系調查を行った。本 調査地域においては $\mathrm{A}$ 層と $\mathrm{B}$ 層の化学的性質よ り，B層の厚さや「軟らかさ」などの物理的性質が 整っていることの方が, 樹木の成長に支配的である ことを明らかにし，その結果を踏まえて，山腹工施 工当初の配慮事項を提案した。

\section{引用文献}

1）阿部和時：樹木根系の斜面崩壊防止機能，森林科 学, 22, 23-29, 1998

2）細川秀一・岡崎慎一・吉野 睦・鈴木玲治：瀬田川 砂防管内の砂防植栽地における植生及び土猿の回 復状況一過去 100 年間の推移一, 砂防学会誌, 50 (4), 30-34, 1997

3）近畿地方建設局琵琶湖工事事務所：瀬田川砂防調 查報告書「田上山地土砂生産流出解析」(XVII), 28-46, 1995

4）森本幸裕：斜面緑化，鹿島出版会，1982

5）日本河川協会編：建設省河川砂防技術基準（案）同 解説設計編 [II], 山海堂, pp. 27-28, 1998

6）森林土猿研究会編：森林土壤の調べ方とその性質, 
林野弘済会, pp. 71-99，1982

7）鈴木雅一・福嶌義宏：風化花崗岩山地における裸地 と森林の土砂生産量, 水利科学, No. 190, 89-100, 1989

8）塚本良則：森林は山地の侵食防止にどのように機
能しているか，森林科学，22，2-9，1998

9）塚本良則：森林・水・土の保全, 朝倉書店, pp. 8088, 1998

(1999. 9. 6 受理)

\section{Summary}

When an objective of the construction and maintenance of the hillside work in erosion and sediment control work is decided, it is necessary to consider the followings: 1) Does vegetation grow sufficiently to cover the ground? 2) Is $A_{0}$ layer formed by the supply of the litter? 3) Is the development of the root system sufficient? 4) Is the plant community which can make its natural succession independent of artificial control formed? 5) Is the soil which bear the growth of the natural seeded vegetation secured?

The investigation of the relationship between the development of the root system and the soil condition was carried out on the hillsides in Tajimi-city, Gifu Pref. The development of the root system was comparatively satisfactory in the layer where the softness value was larger than about $1.0 \mathrm{~cm} /$ drop. However, the development of a minute root was obstructed in the layer where the permeability was poor. It was thought that there was little problem in the growth of the native species though the $\mathrm{pH}$ showed a strong acid content of about 4.0 in the chemical characteristic investigation. The activeness of the vegetation in the districts where brown forest soil was formed was excellent though there was a tendency of a lack of nourishment in the B layer. It is important to be aware of the solidity, permeability and the nourishment of the soil regarding the development of a foundation when hillside work is to be carried out. 